\title{
基盤不整形性の影響の設計震度スペク外ルへの 導入に関する基礎的検討
}

江尻讓嗣 $*$ 後藤洋三**

\begin{abstract}
表層地盤が比較的軟弱で基盤層との動的剛性比IPが小さい場合には表層地盤の共振現象 や地盤の不整形性の影響による地震動の増幅が生じやすい.ここでは, 数 $10 １ 00 \mathrm{~m}$ 程度の 規模の基盤不整形構造が地震動に及はす影響を F E M地震応答解析により調査し，その結 果と弾性波動諭に基づき, 基盤不整形構造が地震動に及ほす影響を地震荷重を表す設計震 度スペクトルの形で簡易的に予測評価する方法を提案した。
\end{abstract}

Key Words: topographical irregularities, basin, inclined base layer, soil response analyses, simple formulation

\section{1．まえがき}

構造物に作用する地震荷重としての地震動を予測する ことは地震工学において重要な研究課題の一つである.

現在, この地震動特性を予測する際には影響要因を, 震源・伝播経路・局所的地盤条件の 3 つに分けて考元る ことが一般的である.震源の問題は, 近年の理論断層モ デルや半経験的断層モデル手法の進渉により断層の破壊 過程の地震動への影響をある程度の精度で取り込むこと が可能になってきており, 現在も精力的な研究が進めら れている．伝播経路に関しては地震波が最も長く留まる 媒質であるという意味において特に地震動特性への影響 が大きな要因であるが, 構造, 物性の情報量の不足と複 雑さのためか, 地震観測記録を用いたインヴァージョン 手法による減衰能 $\mathrm{Q}$ 值の評価や経験的なアテニュエー ション等を対象とした研究が多い.

最後の局所的地盤条件は, 過去の多数の地震被害の分 布が構造物が建設されている地点の表層地盤条件あるい は周辺のやや広い領域での地質条件と良く対応すること から，古くから注目されてきた．しかしながら，既往の 研究では, 局所的な地盤条件や地質条件の相異が地震動 特性に及ほす影響としてて地震動特性（特に最大加速度 等）と表層地盤の物性との関連が主に論じられており, 現実の地形や地盤構成を非常に理想化した形で, 特に構 造物周辺の極く限られた領域のある深さまでを，水平方 向に無限に連続する水平成層地盤の一部のように見なし て問題を取り扱うことが多い. 例えば1989年のロマ プリエ夕地震では, サンフランシスコ湾岸地域に広く分 布するべイマッドと呼称される軟弱粘性土からなる地層 による地震動の顕著な増幅が水平成層地盤の増幅として 注目を集めたことは記憶に新しい1)。

\footnotetext{
*正会員 工修 (株) 大林組技術研究所 土木第五研究室

（†204 東京都清瀬市下清戸4-640）

**正会員 工博. (株) 大林組技術研究所 土木第五研究室 室長
}

しかし，地盤上での地表面地震動が上述のような理想化 された条件を満たすような例は現実には多くは存在しな い.すなわち，何らかの形で地盤の不整形性の影響が地 震動特性に含まれているものと考えられる。

不整形構造が地震動特性に及ほす影響に関する既往の 研究については, 地震学的立場からの解析的アプローチ が主で定性的な議論がなされることが多かった．例えば 1985 年のメキシコ地震の際にメキシコシティーで観 測された継続時間の長い周期数秒の地震動成分の生成 は，その堆積盆地構造に起因することが定性的ではある が解析により確かめられている2).

ところが，現状ではこのような不整形構造が地震動特性 に及ほす影響に関する研究から得られた知見が構造物の 耐震設計や防災対策に十分に反映されているとは言い難 い. その理由として, 地震学で取り扱う不整形構造の次 元（数10 100 k mのオーダー）が実構造物のそれに比べ てはるかに大きいこと, 構造物建設地点の地盤の不整形 構造に関する情報が不足していること, 工学的アプロー チを試みた研究であってもその成果がケースス夕デイ的 であったこと等が考えられる31. そこでこの研究では, 工学的次元（数 $10 \sim 100 \mathrm{~m}$ のオーダー）での不整形構造の 地震動に及ほす影響を検討し,さらに設計段階において その影響を地震荷重を表す設計震度スペクトルの形で簡 易的に予測評価する方法を検討した.

この報告の第 2 章ではFEM地震応答解析により代表的 な基盤不整形構造が地震動特性に及ほす影響について調 査した内容を述べる. 第 3 章では第 2 章の結果を基に基 盤不整形構造による地盤応答特性を簡便に予測評価する 式を提案する，第 4 章では既往の解析例や観測例に見ら れる地盤応答と評価式によるそれとを比較することによ りここで提案した評価式の適用性を検討する。第 5 章で は本論文のまとめと今後の課題について言及する. 




2. F E M地震応答解析による 代表的不整形構造の影響評価

設計震度スペクトルに簡易的に不整形構造の影響を取 り込むためには，まず不整形構造と表層地盤の物性が表 層地盤の地震応答特性に及ぼす影響の全体像を概略では あれ明らかにする必要がある。

過去の研究において地震観測や解析的アプローチによ りこれらの特性を明らかにしようとする試みが多数行わ れてきたが，個々が独立したケーススタデイで類型的に まとめることが困難であった，そのため，ここでは F E M地震応答解析によるパラメトリックなケーススタデイ をできるだけ多数行い, 不整形構造の影響を簡易的にモ デル化するための標本群を作成した.

\section{(1) 不整形構造}

代表的な不整形構造として表層地盤と基盤層からなる 2 層系の基盤不整形を取り扱うこととし，Fig.1に示すよ うな片側が傾斜基盤で反対が開放されている片側傾斜(以 下, S タイプ)と堆積盆地状の両側傾斜(以下, Dタイプ) の 2 種類について検討した. S タイプの場合は基盤の傾 斜勾配を $1 / 1,1 / 2,1 / 4$ と変えた S $1, \mathrm{~S} 2, \mathrm{~S} 3$ の 3 モデル, D夕 イプは両側の基盤傾斜勾配を $1 / 2$ に固定し盆地底幅を傾斜 部水平距離の0,1,2倍としたD1,D $2, \mathrm{D} 3$ の 3 モデルとし, 合計 6 種類の不整形構造モデルについて地震応答解析を 実施した. 地震応答解析では，すべてのモデルにおいて 表層地盤の最大層厚Hを $20 \mathrm{~m}$ に設定した.

（2）地盤物性

地盤が層構造を成す場合には層間の動的剛性比IP(波動 インピーダンス比によって震動振幅の増幅率が大きくな ることが地震観測や解析により明らかになっている.

そこで, ここでは不整形構造における表層地盤と基盤 層の動的剛性比IPを重要なパラメー夕と考え $1 / 6,1 / 4,1 / 3,1 /$ 2の4種類に設定した. 個々の地盤層の具体的な物性値に
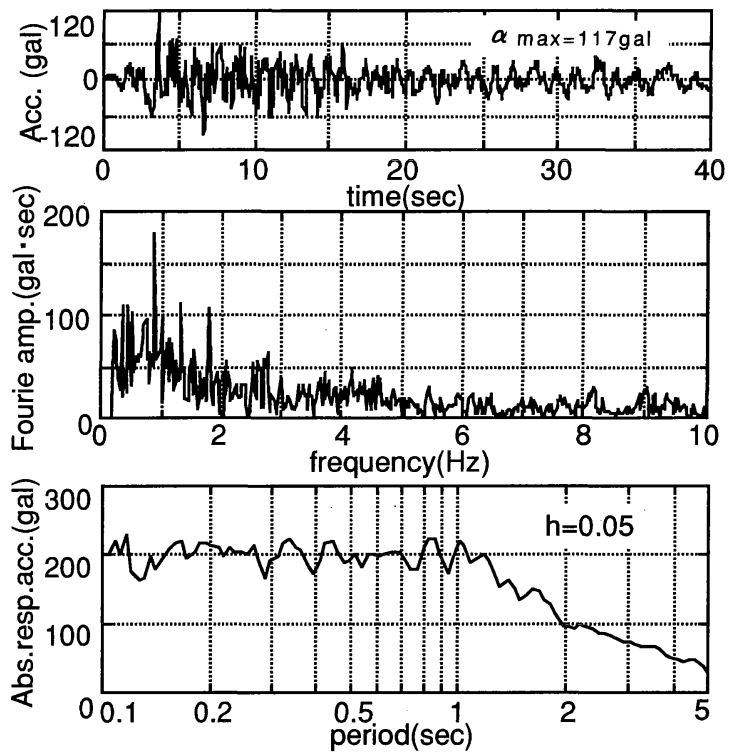

Fig.2 Input motion characteristics
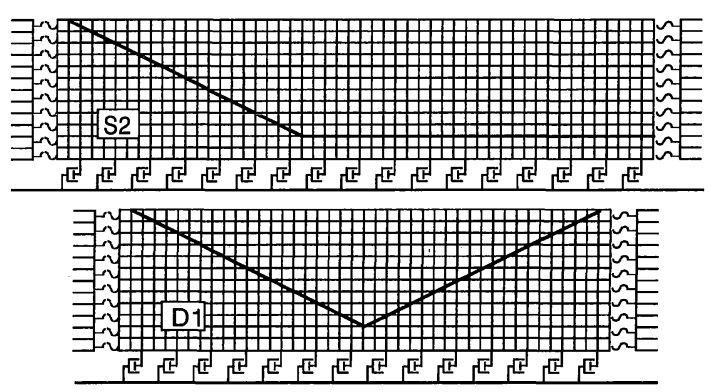

Fig.3 Example of FEM models
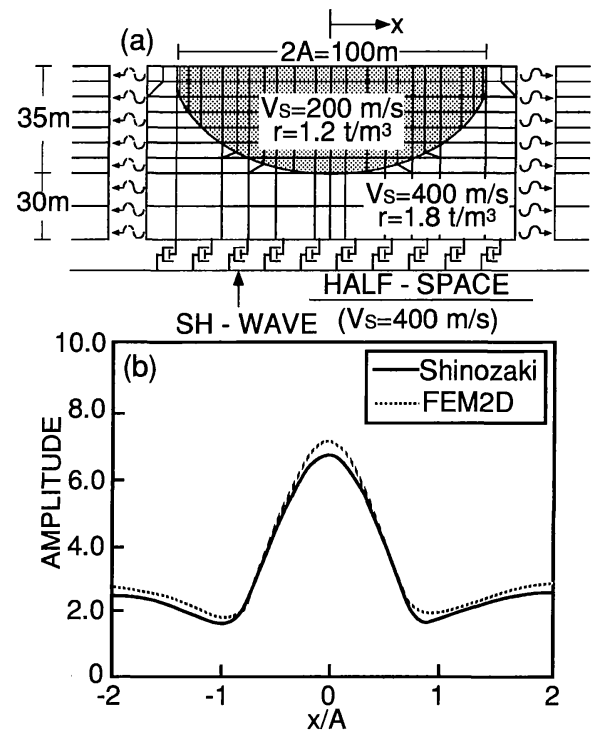

Fig.4 Comparison between FEM2D and BIEM

ついてはTable 1に示したものを用いた．地盤材料はすべ て線形弾性材料とし, 内部減衰を履歴減衰として表層地 盤,基盤層ともに5\%とした. 


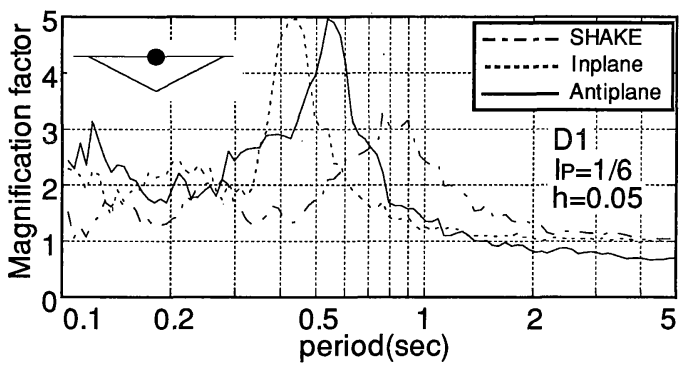

Fig.5 Amplification for each exciting direction on D1



Fig.6 Amplification against SHAKE for each exciting direction on D1

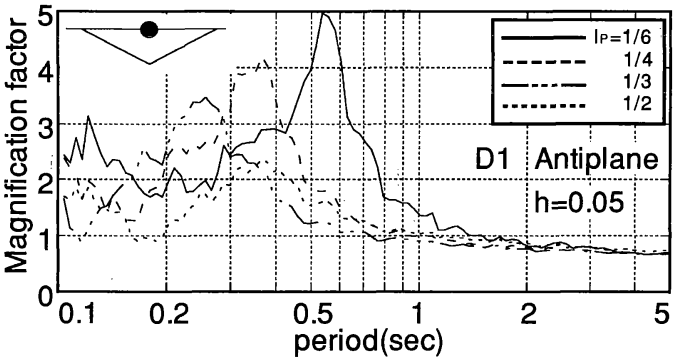

Fig.7 Amplification for each IP on D1
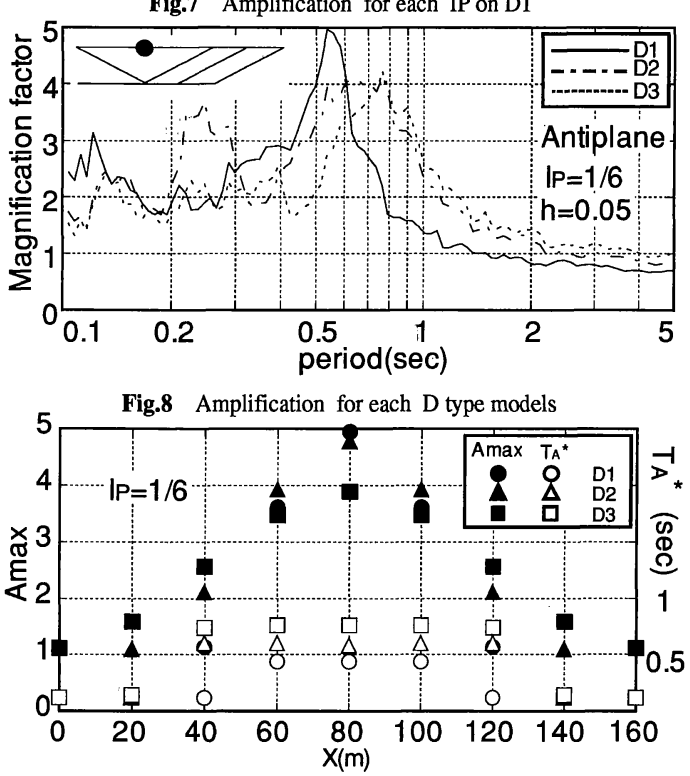

Fig.9 Distribution of Amax and predominant period on D type

(3) 入力地震動

まず，道路橋示方書・同解説 $\mathrm{V}$ 耐震設計編4) に記載され ている第I種地盤上の標準加速度応答スペクトル $(\mathrm{h}=0.05)$

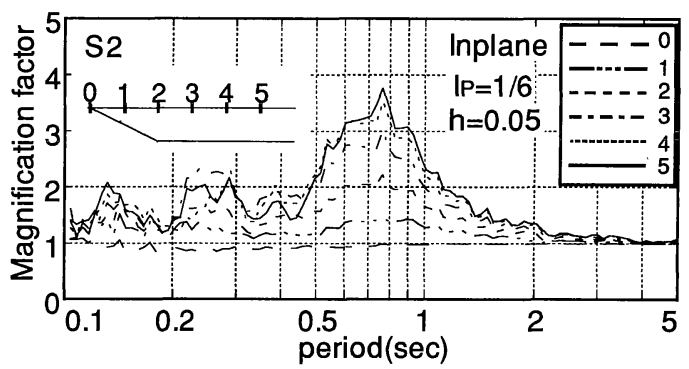

Fig.10 Amplification for each positions on S2

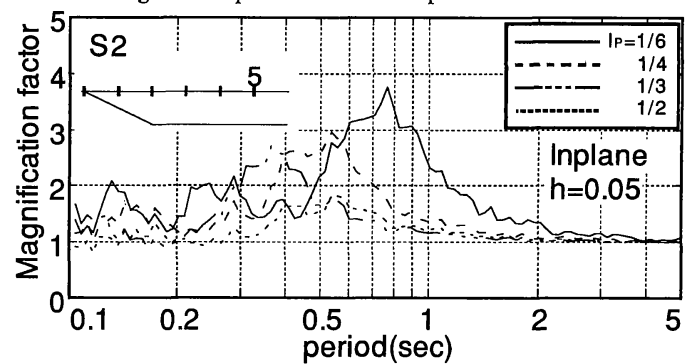

Fig.11 Amplification for each IP on S2
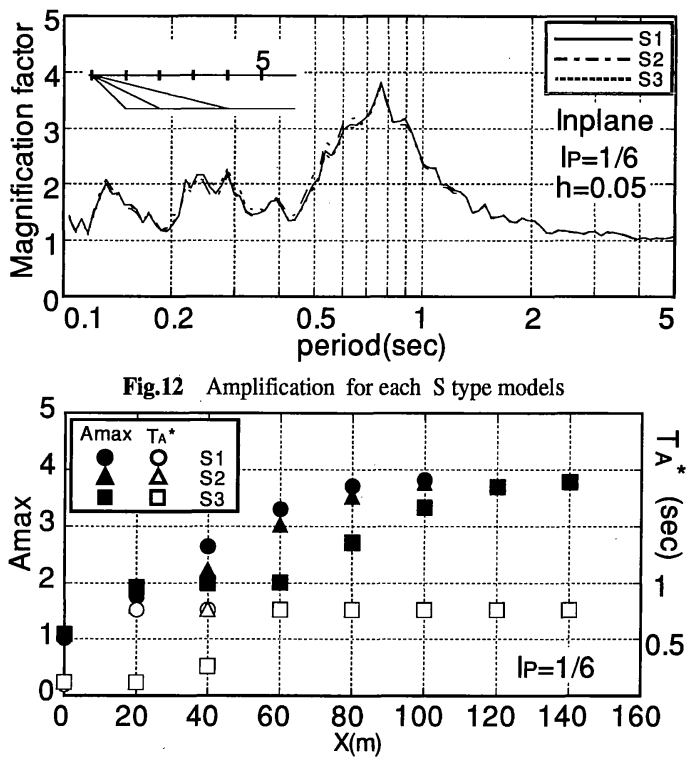

Fig.13 Distribution of Amax and predominant period on $S$ type

を解放基盤の設計震度スペクトルと考えてこれに適合す るようにTAFT EW(1952),ELCENTRO NS(1940), 開北橋 $\mathrm{TR}(1978)$ の 3 地震波を修正し入力地震動(2E)を作成し た. その後, 後述する水平成層地盤の地震応答解析にお いて最大応答を示すTAFT波の修正波(以下,TAFT修正波最大加速度 $117 \mathrm{gal}$ )を不整形構造の地震応答解析用入力地 震動として選定した. Fig.2にはTAFT修正波の時刻歷, フーリエ振幅スペクトルならびに絶対加速度応答スペク トルを示す.

\section{(4) 解析方法}

加振方向は面内 ( S V 入射) と面外 ( S H 入射)の水平方向 で, 前節で作成した入力地震動の振幅を $1 / 2$ 倍した波形を 
基盤からの入力として入射波解析を実施した. 入射方向 は軟弱な表層地盤を対象としていることから鉛直下方と した. 解析コードとして面内はFLUSH ${ }^{5)}$ 改良版を, 面外 はFEM2D）を用いた. Fig.3には一例としてS2とD1モデ ルのF E M 要素分割図を示す. 境界処理は, 面内·面外と もに底部に粘性境界，側部については波動伝達境界を用 いた。Fig.4(b)には，FEM2Dと境界積分方程式法 $(B I E M)^{7)}$ による堆積盆地の応答解析結果の比較を示す. 同図(a)に示したモデルに振動数 $1.5 \mathrm{~Hz}$ の単位変位振幅を持 つS H 波を鉛直下方入射した時の地表面変位応答を比較 したものである.この図からFEM2Dが十分な解析精度を 持っていることが分かる. FLUSHの解析精度は過去に多 数の解析例も有ることから詳細は文献5)に譲る.

\section{(5) 解析結果}

a) Dタイプ

Fig.5には，D1モデルの堆積盆地中央における地表面応 答の加速度応答スペクトル $(\mathrm{h}=0.05)$ の解放基盤設計震度 スペクトルに対する比(以下, 増幅率)を示す. 不整形構造 の最大表層地盤厚 $\mathrm{H}$ と等しい表層地盤厚を持つ水平成層 地盤の増幅率(図中のSHAKE) と比べて面外, 面内の両者と も増幅率は大きくなりその卓越周期は短周期側にシフト する. 面外と面内の最大増幅率(Amax)の值については大 差はないが卓越周期の短周期側へのシフトの度合は面内 の方がやや大きい.この傾向は, 盆地中央地表面におけ る応答の加速度応答スペクトルの水平成層地盤地表面応 答のそれに対する倍率を描いたFig.6からも明らかであ る. Fig.7にはD1モデルの盆地中央地表面における動的剛 性比IP別の増幅率を示す. 動的剛性比が小さくなるにつ れて最大増幅率は大きくなる。 また, 卓越周期 $\left(\mathrm{T}_{\mathrm{A}}{ }^{*}\right)$ は表 層地盤のS 波速度に対応して変化する. Fig.8にはD夕イ プ面外の盆地中央地表面の不整形構造別増幅率を示す. この図から盆地幅が狭くなるほどその最大増幅率は大き くなり卓越周期も短周期になることがわかる. 盆地幅が 広がるにつれて盆地中央の地表面応答は水平成層地盤の それに漸近していくことがわかる．Fig.9には最大増幅率 と卓越周期の地表面に沿った分布を示す。この図から最 大増幅率は盆地端部から盆地中央に向かって大きくなる ことがわかる. 卓越周期は, 基盤平坦部でほほ地表面に 沿って一定值をとり盆地幅が広くなるほど長くなる.

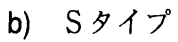

Fig.10には，S 2 モデル面内の傾斜端部からの距離別の 増幅率を示す．傾斜部では表層地盤が厚くなるにつれて 増幅率が次第に大きくなってゆく．傾斜端部から最大表 層地盤厚の 5 倍の距離の地点 5 までその増幅率は増加し水 平成層地盤のそれよりもやや大きくなっている．正弦波 を入力した場合には傾斜境界部やその近傍で増幅率が大 きくなる地点が局所的に現われることが知られている が，地震波を入力した場合にはそれらが平均化され，顕

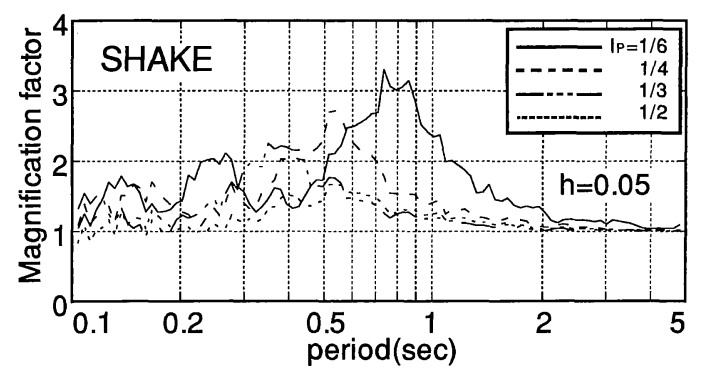

Fig.14 Amplification calculated by SHAKE for each IP

著な増幅が認められなくなる. 卓越周期は傾斜部ではや や短周期成分が卓越するが基盤が平坦になる領域では水 平成層地盤の值にほほ等しい. Fig.11には傾斜端部から最 大表層地盤厚の 5 倍の距離の地点5における面内の動的剛 性比別の増幅率を示す. 一般的傾向はほぼDタイプの場 合と同じであるが最大増幅率, 卓越周期ともにDタイプ に比べて水平成層地盤のそれに近い.Fig.12には，S夕イ プ面内の傾斜勾配別の増幅率を示す。この図からは傾斜

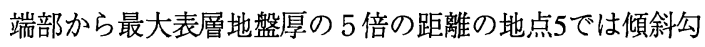
配が大きくなるほどやや増幅率が大きくなるように見え る.しかしFig.13に示した最大増幅率の地表面に沿った分 布を見ると, 傾斜勾配は最大増幅率の絶対值というより はむしろそれを生ずる位置に影響することがわかる.

3. 設計震度スペクトルを用いた 不整形地盤応答特性評価式

この章では前章のパラメータスタディで求めた不整形 構造と表層地盤の物性による増幅特性を簡易に設計震度 スペクトルの形に導入する方法と地表面上の任意の地点 での増幅特性の評価式について述べる.

(1) 増幅関数のモデル化

基盤構造の不整形性と表層地盤の軟弱性（動的剛性比 に依存）の両者の影響を表現する増幅関数 $\mathrm{Cs}(\mathrm{T})$ を線形 1 自由度系の伝達関数と相似の式(1)で定義する.

この増幅関数を第 I 種地盤上の設計震度スペクトル(解 放基盤加速度応答スペクトルに相当)に乗ずることにより 目的とする設計震度スペクトルを求めることができるも のとする．ただ $\mathrm{Cs}(\mathrm{T}) \leqq 1$ の時は $\mathrm{Cs}(\mathrm{T})=1$ とする.

$$
\operatorname{Cs}(\mathrm{T})=\frac{1}{\sqrt{\left(1-\frac{\mathrm{T}_{\mathrm{A}}^{*}}{\mathrm{~T}^{2}}\right)^{2}+\left(\frac{\mathrm{T}_{\mathrm{A}}{ }^{*}}{\mathrm{~T}}\right)^{2} / \mathrm{Amax}^{2}}}
$$

ここにTは周期 (秒), $A \max$ は最大増幅率, $\mathrm{T}_{\mathrm{A}}{ }^{*}$ は最大 増幅率を生ずる周期（秒）をそれぞれ示している．この 増幅関数はAmaxと $\mathrm{T}_{\mathrm{A}}{ }^{*}$ の 2 つのパラメータによりその形 状が決まる. Amaxと $\mathrm{T}_{\mathrm{A}}{ }^{*}$ は当然のことながら不整形構造 と表層地盤の軟弱性ならびに注目地点の位置に影響され るパラメータである，ここでは，Amaxを水平成層地盤構 




Fig.15 Comparison between SHAKE,KANAI and EQ. on AHmax 造を鉛直方向に伝播する波動による最大増幅率AHmax と 鉛直下方から波動が入射した時に不整形構造に帰因して 側方境界面から生ずる水平方向伝播波動による最大増幅 率Aimax(i=S;片側傾斜,D;両側傾斜を意味する)との自乗和 平方根として次式で求めることとした。

$$
A \max =\sqrt{\mathrm{Armax}^{2}+\mathrm{Aimax}^{2}} \quad(i=S, D) \cdots(2)
$$

AHmaxは不整形構造の地表面上の任意の地点における表 層地盤厚を持つ水平成層地盤の最大増幅率として定義さ れる. Aimaxについては(3)ならびに(4)節にて詳述する. これらの自乗和平方根を用いた理由は両者の最大増幅率 が必ずしも同一周期に生ずるとは限らずこれらの単純和 ではその影響を過大評価する恐れがあることから適当な 按分を計ったためである. 第 2 章に示した代表的不整形 構造の地震応答解析結果もその増幅特性はほほ単峰形を しており，以上の仮定は妥当なものと考えられる.

(2) 水平成層地盤の最大増幅率

前節で述べた最大増幅率AHmaxをモデル化するために 水平成層地盤の地震応答解析を $\mathrm{S}$ 波重複反射理論により 実施した．表層地盤厚は $20 \mathrm{~m}$ とし地盤物性はTable 1のも のをそのまま用い動的剛性比IPをパラメータとして整理 した. Fig.14には水平成層地盤地表面応答の加速度応答ス ペクトル $(\mathrm{h}=0.05)$ の第 $\mathrm{I}$ 種地盤上の標準加速度応答スペク トルに対する比(増幅率)を示した. この図から動的剛性比 IPが小さいほどAHmaxが大き：なることがわかる.

この関係を次式に示す様なIPの関数としてモデル化し水 平成層地盤の最大増幅率を評価することとした.

$$
\begin{aligned}
& \text { AHmax }=\beta * \sqrt{\frac{2}{\mathrm{IP}_{P}}} \quad \ldots \ldots \ldots \ldots \ldots \ldots \ldots \ldots \\
& \mathrm{Hx} \leq 35 \mathrm{~m} \quad \beta=0.8 *\left\{\left[\frac{\mathrm{Hx}}{\mathrm{H}_{0}}\right]^{2}+0.25\right\} * \exp \left\{1-\left[\frac{\mathrm{Hx}}{\mathrm{H}_{0}}\right]\right\} \\
& \mathrm{H}_{0}=20 \mathrm{~m}
\end{aligned}
$$

$\mathrm{Hx}$ は地表面上の任意の地点での地表面から基盤までの 深度 $(\mathrm{m})$ である． $\beta$ は表層地盤の深さがAHmaxに与える影 響を補正する係数で $\mathrm{Hx}$ と基準深度 $\mathrm{H} 0$ の関数で定義され る. 理論的にはAHmaxはIPのみの関数として決まるもの であるが，軟弱地盤における地震観測の成果を理論計算

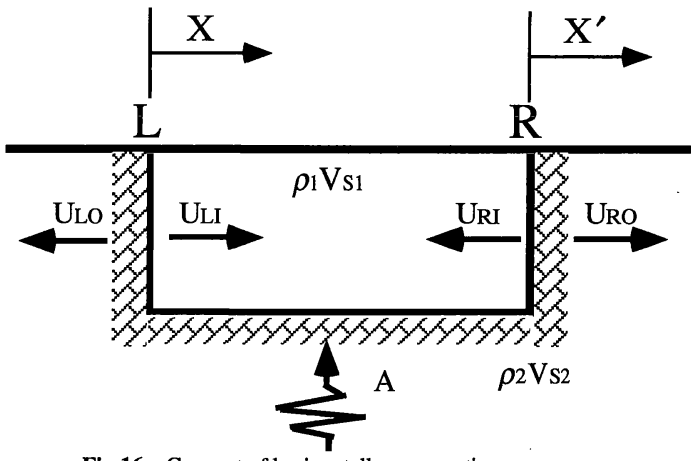

Fig.16 Concept of horizontally propagating waves

に取り込んだ結果8)によればその最大増幅率は軟弱地盤 の層厚にも依存していることが明らかになっており，そ れを盛り込んだものである。補正係数に上限を設けたの は基盤深度がある程度以上になると最大増幅率を生ずる 周期が基盤地震動の卓越周期成分の範囲から長周期側に ずれて実質的に増幅度が減少することを考慮したもので ある. 弾性波動論によれば非減衰の 2 層系へ正弦波が入 力する場合AHmaxの值は1/IPとなるが，ここでは現実の地 震波が不規則波であることや表層地盤の減衰性等を考慮 して理論值の 2 倍の平方根をAHmax とした. Fig.15には 地震波を入力した動的応答解析結果(SHAKE)とモデル化 したAHmaxの比較を示す。また，同図中には金井8)によ り求められた最大増幅率を合わせ示した。この図から評 価式は他に比べてやや大きめ（安全側）の值を与えるも のの応答解析により求められたAHmax とIPとの関係をう まく表現していることがわかる.

（3）水平方向伝播波動により生ずる最大増幅率の誘導

今, Fig.16に示すような堆積盆地状の不整形構造に鉛直 下方より振幅 $\mathrm{A}$, 角振動数 $\omega$ の正弦波が入射した時, 左 右の不整形境界面L,Rのそれぞれにおいて堆積盆地の内ま たは外方向に向かって水平に伝播する波動が生ずると仮 定する．実際に生成している波動は実体波と表面波が混 在し, 複雑な多重反射が生じていると考えられるが, 重 要な点は多重反射による振動エネルギ-の増幅であるの で，ここではS波成分に仮に注目して多重反射を記述す る. 境界面LおよびRで発生する水平方向伝播波動をそれ ぞれULO,ULI,URO,URI(添字O;OUT,I;IN)とするとそれらは 次式のように表現できる9).

$$
\begin{aligned}
& \text { ULO }=\mathrm{B} * \exp ^{\mathrm{i} \omega\left(\mathrm{t}+\frac{\mathrm{x}}{\mathrm{Vs} 2}\right)} \\
& \text { ULI }=C * \exp ^{i \omega\left(t-\frac{x}{V s 1}\right)} \exp ^{-\eta x} \\
& \mathrm{URO}_{\mathrm{RO}}=\mathrm{E} * \exp ^{\mathrm{i} \omega\left(\mathrm{t}-\frac{\mathrm{x}^{\prime}}{\mathrm{V}_{\mathrm{s} 2}}\right)} \\
& \mathrm{URI}=\mathrm{D} * \exp ^{\mathrm{i} \omega\left(\mathrm{t}+\frac{\mathrm{x}^{\prime}}{\mathrm{V}_{\mathrm{s} 1}}\right) \exp \eta \mathrm{x}^{\prime}}
\end{aligned}
$$

ここに, B,C,D,Eはそれぞれの波動の振幅を $\exp ^{-\eta} \mathrm{x}_{\text {項は }}$ 堆積盆地内での距離減衰を近似的に取り入れるためのも のである. 堆積盆地外の基盤における距離減衰は堆積盆 地内のそれに比べて極めて小さいと考えて省略した. 


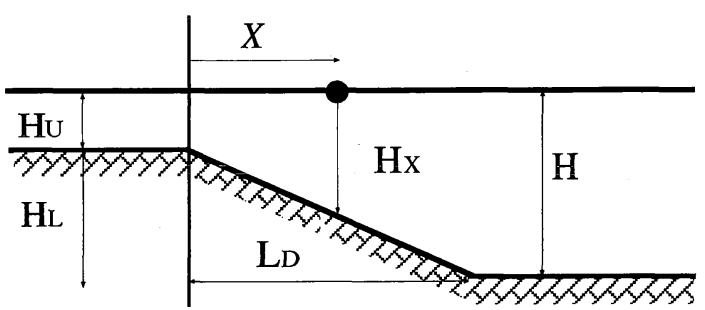

Fig.17 Inclined base layer(S type)

これらの波動は境界面しおよびRのそれぞれにおいて変 位と応力の連続条件を満たす必要があることから以下の 連立方程式か誘導される.

$$
\begin{aligned}
& \mathrm{B}=\mathrm{C}+\mathrm{D} \Phi \quad \mathrm{E}=\mathrm{C} \Phi+\mathrm{D} \\
& \alpha_{\mathrm{L}} \mathrm{B}+\mathrm{CIP}-\mathrm{D} \Phi \mathrm{IP}_{\mathrm{P}}-\mathrm{f} \alpha_{\mathrm{L}} \mathrm{IP}=0
\end{aligned}
$$

$-\mathrm{C} \Phi \mathrm{IP}+\mathrm{DIP}+\alpha_{\mathrm{R}} \mathrm{E}+\mathrm{f} \alpha_{\mathrm{R}} \mathrm{IP}_{\mathrm{P}}=0$

$$
\begin{aligned}
& \mathrm{IP}=\frac{\rho_{1} \mathrm{~V}_{\mathrm{s} 1}}{\rho_{2} \mathrm{~V}_{\mathrm{s} 2}} \quad f=\frac{\mathrm{F}}{\rho_{\mathrm{1}} \mathrm{V} \mathrm{si} \omega} \\
& \Phi=\exp ^{-\mathrm{Lw}\left(\frac{\mathrm{i} \omega}{\mathrm{V}_{\mathrm{s} 1}}+\eta\right)}
\end{aligned}
$$

ここに, Lwは堆積盆地幅， $\alpha \mathrm{L}, \alpha$ Rは左右境界面の閉 塞率で基盤が左右で地表まで達する場合は1, Fig.16のよ うに地表まで達していない場合にはそれぞれHLL/H,HLR/H とし境界面LおよびRで部分的に変位と応力の連続条件が 満足されるものとした.VSi, $\rho$ i は微小ひずみ域での S 波 速度ならびに密度 $(\mathrm{i}=1$; 表層地盤, $\mathrm{i}=2$; 基盤層)である.

Fは，振幅Aの波動が鉛直下方より不整形構造に入射し た時に境界面LおよびRに生ずる仮想の力を表現したもの でここでは次式で定義する.

$$
\mathrm{F}=\kappa \frac{\mathrm{G}_{1}}{\mathrm{~V}_{\mathrm{s} 1}} \mathrm{i} \omega\left(\frac{1}{\mathrm{I}_{\mathrm{P}}}-1\right) \mathrm{A}
$$

ここにG1は表層地盤のせん断剛性， $\kappa$ は未知の変換倸 数であるがここでは $\kappa=2$ とした．式(5)の連立方程式を 解くことにより境界面より堆積盆地内へ伝播する波動の 振幅CおよびDはそれぞれ以下のようになる.

$$
\begin{aligned}
& \mathrm{C}=\frac{\operatorname{IPf}\left\{\left(\alpha_{\mathrm{R}}+\mathrm{IP}\right) \alpha_{\mathrm{L}}+\left(\alpha_{\mathrm{L}}-\mathrm{IP}_{\mathrm{P}}\right) \alpha_{\mathrm{R}} \Phi\right\}}{\left\{\left(\alpha_{\mathrm{R}}+\mathrm{I}_{\mathrm{P}}\right)\left(\alpha_{\mathrm{L}}+\mathrm{IP}\right)-\left(\alpha_{\mathrm{R}}-\mathrm{IP}\right)\left(\alpha_{\mathrm{L}}-\mathrm{I}_{\mathrm{P}}\right) \Phi^{2}\right\}} \\
& \mathrm{D}=\frac{-\mathrm{IPf}_{\mathrm{P}}\left\{\left(\alpha_{\mathrm{L}}+\mathrm{I}_{\mathrm{P}}\right) \alpha_{\mathrm{R}}+\left(\alpha_{\mathrm{R}}-\mathrm{IP}\right) \alpha_{\mathrm{L}} \Phi\right\}}{\left\{\left(\alpha_{\mathrm{R}}+\mathrm{I}_{\mathrm{P}}\right)\left(\alpha_{\mathrm{L}}+\mathrm{IP}_{\mathrm{P}}\right)-\left(\alpha_{\mathrm{R}}-\mathrm{IP}\right)\left(\alpha_{\mathrm{L}}-\mathrm{I}_{\mathrm{P}}\right) \Phi^{2}\right\}}
\end{aligned}
$$

片側のみに基盤傾斜がある場合は谷幅 $L \mathrm{~W} \rightarrow \infty$ と考える と $\Phi \rightarrow 0$ となる. さらに左側傾斜を考えて $\alpha \mathrm{R}=0$ としこ れらを上式に代入して整理すると増幅率Asは次式のよう になる。

$$
\mathrm{A}_{s}=\frac{|\mathrm{C}|}{2 \mathrm{~A}}=\frac{\alpha_{\mathrm{L}}(1-\mathrm{IP})}{\alpha_{\mathrm{L}}+\mathrm{IP}}
$$

ここでは片側傾斜の場合を取り扱っているので左右対 称性を考慮して $|\mathrm{C}|=|\mathrm{D}|, \alpha=\alpha \mathrm{L}=\alpha \mathrm{R}$ として整理 すると結局片側傾斜の場合の増幅率Asは次式で表せる.

$$
\mathrm{A}_{\mathrm{s}}=\frac{\alpha(1-\mathrm{IP})}{\alpha+\mathrm{IP}}
$$

ここに $\alpha$ は片側傾斜の閉塞率である. 片側傾斜では水 平方向の多重反射が生じないのでAsは1以上にならない. 両側傾斜の場合には $\Phi$ を最大化することを考えればよ

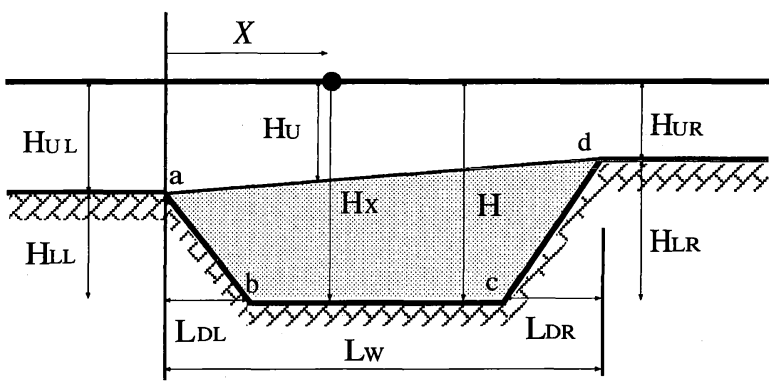

Fig.18 Basin(D type)

いから結局 $\eta \rightarrow 0, \exp ^{-\mathrm{LWi} \omega / \mathrm{VS} 1 \rightarrow 1}$ とした時に $\Phi$ は最 大值 1 となる。この関係を式(8)に代入してを整理すると 両側傾斜の場合の増幅率は左右の傾斜境界による増幅率 をそれぞれADL，ADRとすれば次式のようになる。

$$
\begin{aligned}
& A_{D L}=\frac{|\mathrm{C}|}{2 \mathrm{~A}}=\frac{(1-\mathrm{IP})\left\{\operatorname{IP}\left(\alpha_{\mathrm{L}}-\alpha_{\mathrm{R}}\right)+2 \alpha_{\mathrm{L}} \alpha_{\mathrm{R}}\right\}}{2 \mathrm{I}_{\mathrm{P}}\left(\alpha_{\mathrm{R}}+\alpha_{\mathrm{L}}\right)} \\
& \mathrm{A}_{\mathrm{DR}}=\frac{|\mathrm{D}|}{2 \mathrm{~A}}=\frac{\left(1-\mathrm{IP}_{\mathrm{P}}\right)\left\{\operatorname{IP}\left(\alpha_{\mathrm{R}}-\alpha_{\mathrm{L}}\right)+2 \alpha_{\mathrm{L}} \alpha_{\mathrm{R}}\right\}}{2 \mathrm{IP}_{\mathrm{P}}\left(\alpha_{\mathrm{R}}+\alpha_{\mathrm{L}}\right)}
\end{aligned}
$$

式(10),(11)は不整形構造に正弦波が入射した時の振幅の 増幅率を与えるが，現実の地震波が不規則波であること や表層地盤の減衰性等をして(2)節で水平成層地盤の最大 増幅率を定めた時と同様に式(10),(11)で求められる増幅率 の 2 倍の平方根を最終的な増幅率とした.

\section{(4) 不整形地盤応答特性評価式の提案}

この節では最大増幅率の地表面に沿った分布のモデル 化について述べるが，第2 章(5)節での検討から面内, 面 外の加振方向の相異は増幅率と周期にほとんど影響しな いので，ここでは両者の区別をせずモデル化する.

a) 片側傾斜（Sタイプ）

Fig.17に示す片側傾斜の不整形構造について水平方向伝 播波動による最大増幅率とそれを生ずる周期を以下のよ うに定義した.

$$
\begin{aligned}
\mathrm{T}_{\mathrm{A}}{ }^{*}=\frac{4 \mathrm{Hx}}{\mathrm{V}_{\mathrm{s} 1}} \quad \cdots \ldots \ldots \ldots \ldots \ldots \ldots \ldots \ldots \ldots \ldots \\
\text { Asmax }=\sqrt{\frac{2 \alpha(1-\mathrm{IP})}{(\alpha+\mathrm{IP})}} *\left(\frac{\mathrm{Hx}-\mathrm{HU}}{\mathrm{HL}_{\mathrm{L}}}\right) * \\
\left(\frac{\mathrm{X}}{\mathrm{L}}\right) * \exp \left(1-\frac{\mathrm{X}}{\mathrm{L}}\right)
\end{aligned}
$$

水平方向の場所的な変化は指数包絡関数で表現した. Asmax;水平方向伝播波動による最大増幅率, $\alpha$; 傾斜部の 閉塞率で $\mathrm{HL} / \mathrm{H}, \mathrm{L}$; 傾斜地盤の影響が最大となる傾斜端部か らの距離で, 第2 章でのパラメータスタディ結果から経 験的に次式より求められることとした。

$\mathrm{L}=4 \sqrt{\mathrm{LD} * \mathrm{HL}}$

$\mathrm{X}$; 傾斜端部から当該地点までの距離, $\mathrm{LD}$;傾斜部の水平 距離, $\mathrm{H}$; 表層地盤の最大深さ,Hx;傾斜端部からの距離 $\mathrm{X}$ の 地点の表層地盤の深さで $\mathrm{X} \geqq \mathrm{LD}$ の時はHx=Hとなる. $\mathrm{HL}$; 不整形な基盤の高低差, $\mathrm{Hu}$; 基盤が浅い部分の表層厚

b) 両側傾斜 (Dタイプ)

Fig.18に示す両側傾斜の不整形構造について水平方向伝 



Fig.19(b) Distribution of Amax on S2



Fig.19(c) Distribution of Amax on S3

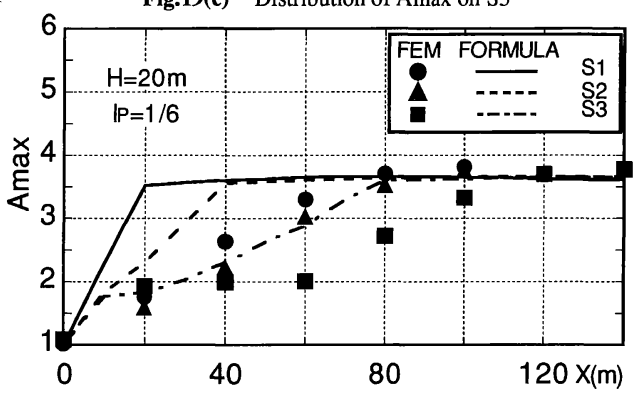

Fig.20 Comparison among $S$ type models

播波動による最大増幅率とそれを生ずる周期を以下のよ うに定義した，両側の傾斜の影響はそれぞれを重ね合わ せることにより取り入れてある.

$$
\mathrm{T}_{\mathrm{A}}{ }^{*}=\frac{4 \mathrm{H}^{\prime \prime}}{\mathrm{V}_{\mathrm{s} 1}}+\frac{4 \mathrm{H}_{\mathrm{U}}}{\mathrm{V}_{\mathrm{s} 1}}=\frac{4}{\mathrm{~V}_{\mathrm{s} 1}} * \frac{\mathrm{S}}{\mathrm{Lw}_{\mathrm{W}}}+\frac{4 \mathrm{Hu}_{\mathrm{U}}}{\mathrm{V}_{\mathrm{s} 1}}
$$

ただし，基盤傾斜部では上式の右辺第一項として $\frac{4 \mathrm{H}^{\prime \prime}}{\mathrm{V}_{\mathrm{s} 1}}$ と $\frac{4(\mathrm{Hx}-\mathrm{Hu})}{\mathrm{V} 1}$ の小さい方を用いて $\mathrm{T}_{\mathrm{A}}^{*}$ を求める.

$$
\begin{aligned}
& A_{D \max }=\sqrt{\frac{\left(1-I_{P}\right)}{\left(\alpha_{L}+\alpha_{R}\right) I_{P}}} * \sqrt{A_{F L}^{2}+A_{F R}^{2}} \quad \cdots \cdots \\
& A_{F L}=\sqrt{I_{P}\left(\alpha_{L}-\alpha_{R}\right)+2 \alpha_{L} \alpha_{R}} *\left(\frac{H x-H U}{H_{L L}}\right) *\left(\frac{X}{L_{L}}\right) * \exp \left(1-\frac{X}{L_{L}}\right)
\end{aligned}
$$


Fig.21(b) Distribution of Amax on D2

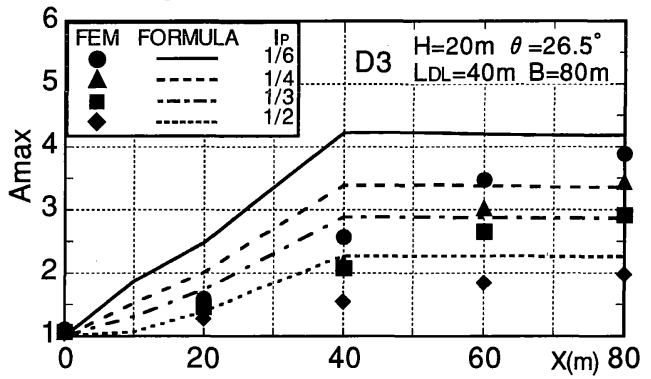

Fig.21(c) Distribution of Amax on D3



Fig.22 Comparison among D type models

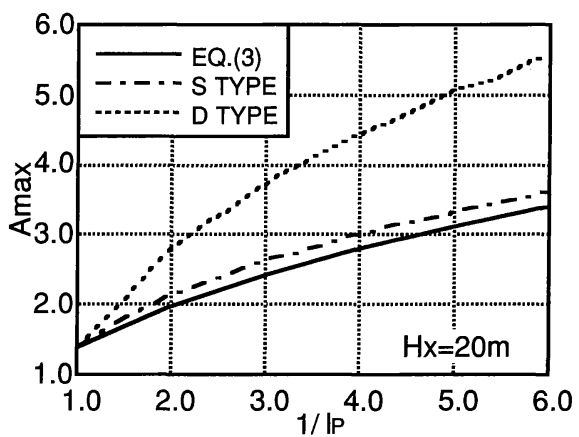

Fig.23 Amax for each topographical types 


$$
A_{F R}=\sqrt{I_{P}\left(\alpha_{R}-\alpha_{L}\right)+2 \alpha_{L} \alpha_{R}} *\left(\frac{\mathrm{Hx}-\mathrm{Hu}}{\mathrm{H}_{\mathrm{LR}}}\right) *\left(\frac{\mathrm{LW}-\mathrm{X}}{\mathrm{LR}_{\mathrm{R}}}\right) * \exp \left(1-\frac{\mathrm{Lw}-\mathrm{X}}{\mathrm{LR}}\right)
$$

ADmax ; 水平方向伝播波動による最大増幅率

$\mathrm{H}^{\prime \prime}$; 両側傾斜堆積盆地の等価深度で次式より求める。

$$
\mathrm{H}^{\prime \prime}=\frac{\mathrm{S}}{\mathrm{Lw}}
$$

$\mathrm{S}$; 堆積盆地の断面積（a,b,c,dで囲まれた面積），

$\alpha \mathrm{L}$; 左側傾斜部の閉塞率で $=\mathrm{HLL} / \mathrm{H}, \alpha \mathrm{R}$; 右側傾斜部 の閉塞率で=HLR/H，LL,LR；片側だけ独立して考えた場 合の傾斜地盤の影響が最大となる傾斜端部からの距離で 次の経験式より求める。

$$
\mathrm{LL}_{\mathrm{L}}=\sqrt{2 * \mathrm{LDL} * \mathrm{H}_{\mathrm{LL}}} \quad \mathrm{LR}_{\mathrm{R}}=\sqrt{2 * \mathrm{LDR}^{2} \mathrm{H}_{\mathrm{LR}}}
$$

$\mathrm{X}$;傾斜端部から当該地点までの距離, LDL,LDR;傾斜部の 水平距離,Lw; 両側傾斜端部間の距離(堆積盆地の幅),

$\mathrm{HX}$; 傾斜端部から Xの距離の地点の表層地盤の深さでLDL $\leqq \mathrm{X} \leqq \mathrm{LW}-\mathrm{LDR}$ の時はHX=Hとなる． $\mathrm{HU}$;傾斜端部から $\mathrm{X}$ の距 離の地点の地表面からadを結ぶ線までの深さ

(5) 評価式と地震応答解析の最大増幅率の比較

ここでは第 2 章で述べた F E M 地震応答解析による最 大増幅率Amax と前節で提案した評価式から求まるそれ との比較を行なう。Fig.19には片側傾斜の S 1，S 2, S 3モデルのAmaxの地表面に沿った分布を示す，いずれの モデルの場合も基盤が平坦な領域では評価式は応答解析 值をうまく再現している。傾斜部では評価式が大きめの 值を示す傾向がある. Fig.20にはIP=1/6とした時の S 1, S 2,S3モデルのAmaxの地表面に沿った分布の比較を示 す。傾斜勾配が小さいほどAmaxが傾斜端部から緩かに 立ち上がる傾向を評価式は再現しているものの傾斜部で の立ち上がり方が応答解析值に比較して急である.

Fig.21には両側傾斜のD1，D2，D3モデルのAmaxの地 表面に沿った分布を示した. いずれのモデルの場合も左 右対称なので盆地中央から左側の領域のみを示す．D1 から D3へと盆地底幅が広くなるにつれて評価式がAmax を過大評価する傾向が見られる．Fig.22にはIP=1/6とし た時の D1，D2，D3モデルのAmaxの地表面に沿った分 布の比較を示す．盆地底幅が狭いほど盆地中央における

Amaxが大きくなる傾向をうまく評価式は再現してい る。しかし，前述したように盆地底幅が広くなるほど評 価式はAmaxを過大評価する傾向がある．これは(3)節に おいて $＼rightarrow 0$ としたことが影響していると思われる.

Fig.23には本章で提案したそれぞれ水平成層地盤,片側 傾斜,両側傾斜の評価式から求まるAmaxの比較を示す. 片側傾斜,両側傾斜についてはそれぞれ式(13),(16)から想 定される極值のAimaxからAmaxを求めた.この図から 片側傾斜場合のAmaxは水平成層地盤のそれに比べ高々 1 割程度大きいだけで不整形構造の影響がそれほど大き くないことがわかる．それに比べて両側傾斜の場合では 動的剛性比IPが小さい時にはAmaxが最大で1.6倍程度に もなり不整形構造の影響が大きいことがわかる.

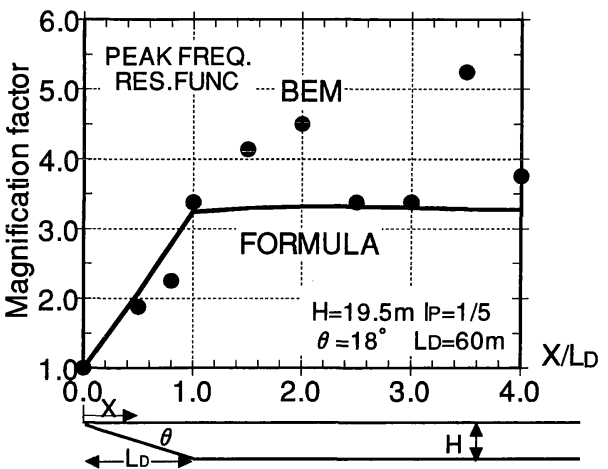

Fig.24 Comparison with BEM

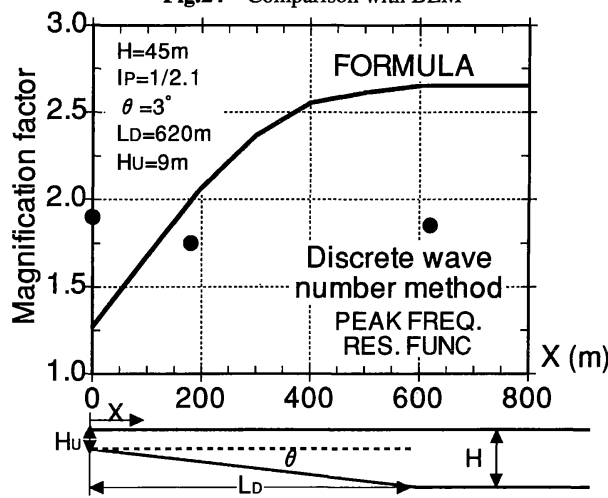

Fig.25 Comparison with DWNM

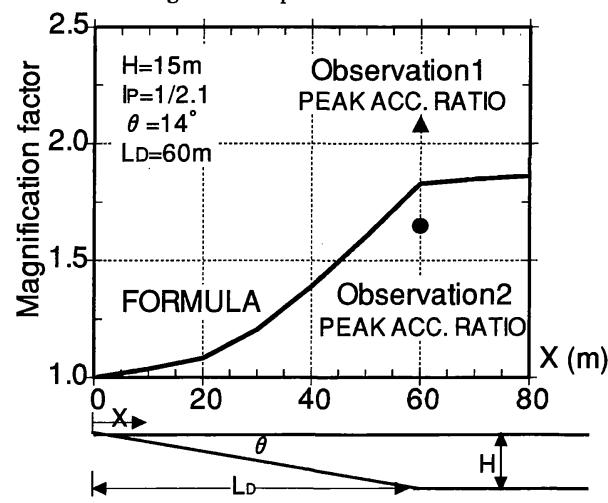

Fig.26 Comparison with Observation

\section{4. 既往の観測・解析例と評価式の比較}

第 2 章, 第 3 章では工学的次元（数 $10 \sim 100 \mathrm{~m}$ のオー ダー）での不整形地盤の地震応答特性が F E M 解析手法 によりシミュレートできるものと仮定して，代表的な不 整形構造について多数のパラメトリックな数值計算を行 い，この結果を基に簡便に不整形地盤の地表面応答を評 価する式を提案した。この評価式をさらに検証するため には，詳細な地盤構造調査に喠付けられた地震観測データ の蓄積が必須であるが，ここではできるたけけ多くの既往 の観測例や解析結果との比較によりこの評価式の適用 性，妥当性の検証を試みる。 




Fig.27 Comparison with BEM and Micro tremor

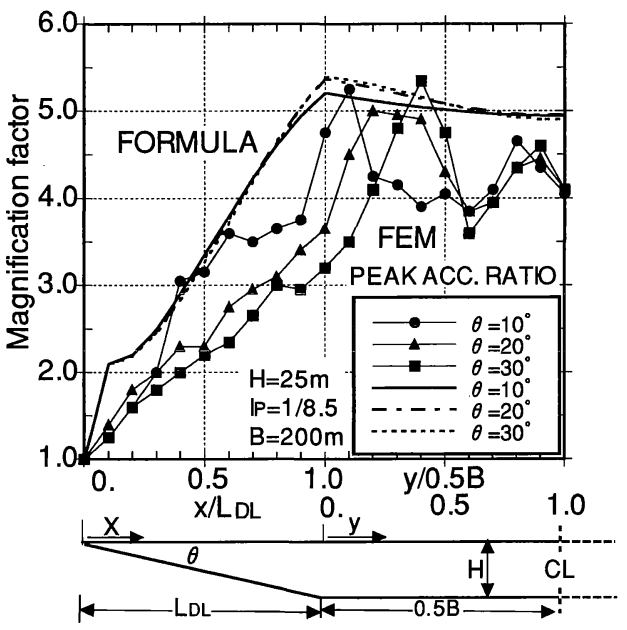

Fig.28 Comparison with FEM

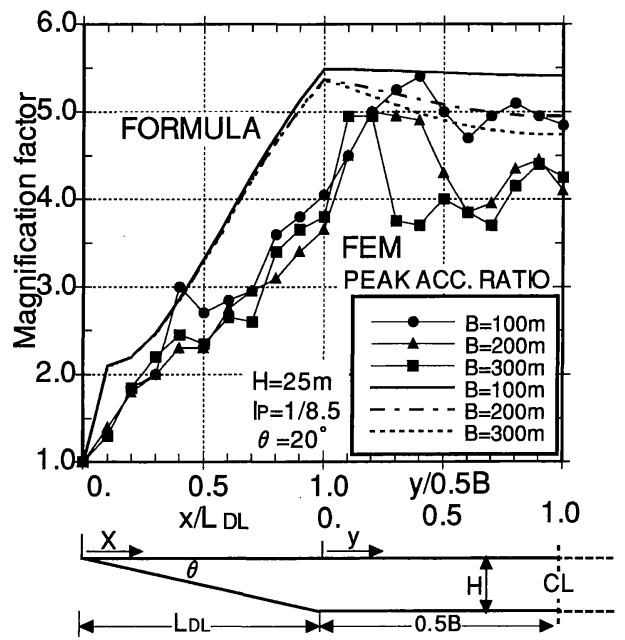

Fig.29 Comparison with FEM

(1) 片側傾斜（Sタイプ）

Fig.24には，片側傾斜の B EM応答解析による周波数伝 達関数 ${ }^{10)}$ と評価式による増幅率の比較を示す. B EMに よる解析值は周波数伝達関数から読み取ったものである ので基盤が平らな部分での変動が激しく值も評価式より
も大きい. Fig.25には，片側傾斜の離散化波数法による周 波数伝達関数11) と評価式による増幅率の比較を示す. 離 散化波数法による解析值は評価式よりも小さい值を示 す。これは，傾斜角が 3 度と非常に小さいことによるも のと考えられる. このような低角の場合は本来, 評価式 の適用範囲外であり, どの程度の低角度まで評価式が適 用できるかは今後の検討課題である．Fig.26には，片側傾 斜の造成地盤における地震観測 ${ }^{12)} に よ り$ 得られた水平最 大加速度比と評価式による増幅率の比較を示す. 評価式 の増幅率は観測值の平均值と良く対応している。

(2) 両側傾斜 (Dタイプ)

Fig.27には, 堆積盆地状の造成地における常時微動観測 結果とそれを対象とした B E M 応答解析の周波数伝達関 数 ${ }^{13)}$ の増幅率と評価式による増幅率の比較を示す. 微動 観測結果と B E M解析結果の両者とも評価式による推定 值よりかなり大きな増幅率を示す.これは表層地盤の減 衰の大きさの相異によるものと思われる. Fig.28には, 堆 積盆地の両側傾斜部の傾斜角をパラメータとした F E M 地震応答解析 ${ }^{14)}$ による水平最大加速度比と評価式による 増幅率の比較を示す．増幅率の絶対值は良く一致してい る. 評価式は，傾斜部において増幅率をわずかであるが 過大評価する傾向があるが, F E M,評価式ともに盆地底 幅が一定であると傾斜部の傾斜角によらずほぼ同じ最大 増幅率を示すことがわかる. Fig.29には, 堆積盆地の底幅 をパラメータとした F E M 地震応答解析 ${ }^{14)}$ による水平最 大加速度比と評価式による増幅率の比較を示す． F EM 解析値に見られるような盆地底幅の変化により最大増幅 率の生ずる相対的位置が变化する傾向も評価式はうまく 表現している.

\section{5. まとめと今後の課題}

本研究では, パラメトリックな F E M地震応答解析結 果を基に， 2 種類の基盤不整形が地表面の地震応答特性 に及は寸影響を, 設計震度スペクトルの形で簡易的に導 入する方法を提案した. これらの評価方法を構築する過 程における問題点と今後の課題について以下に述べる.

\section{(1) 地盤の非線形性と減衰}

今回の解析では, 表層地盤を線形弾性材料と考えて, その材料減衰を $5 \%$ と仮定している，不整形地盤に強震 動が入射した場合には，当然表層地盤の非線形化の影響 が表れる. 最近, 表層地盤の非線形性を考慮して不整形 地盤の応答特性を解析的に検討した例として竹宮等 ${ }^{15)}$, 常田等16) の報告があるが，これらの報告を見ると地表面 に沿った增幅率の分布形状はほとんど線形解析の場合と 差がないように思われる。しかしながらその増幅率の值 には明らかに差が見られる。一般に地盤の非線形化が進 むと表層地盤の平均的なせん断剛性が低下し卓越周期が 長くなり，併せて減衰が増加することにより，増幅率は 小さくなる. 強震時には地盤の減衰は 10 数\%に達すると 
考えられるから， $5 \%$ の材料減衰を仮定した線形解析結 果よりも明らかに増幅率は小さくなる。したがって，こ こで提案した評価式により求まる増幅率は（安全側では あるが）過大評価となる．また卓越周期の変化の影響も 現われる.これらは，地盤材料の非線形挙動を等価線形 化手法により評価し，ここで提案した評価式で不整形地 盤の最大増幅率と卓越周期を決める地盤剛性を等価線形 化した值に置き換えることにより評価できるものと思わ れる．減衰の影響についても簡易的には文献17）等の方 法によって設計震度スペクトルを減衰の相異により調整 することで考慮することが可能であると思われるが，そ の手法の評価は今後の課題としたい.

\section{(2) 不整形構造のディメンジョン}

不整形構造が地震応答特性に及ぼす影響を考える時に 構造自体（形状，寸法）と表層地盤の物性の両者にわけ て考えて見ると（結果的には両者はカップリングする が）特に前者の不整形構造がディメンジョンを持ってい ることからそれと入射する，または入射した波動の波長 との間の相対的な関係が応答特性を決定する主因である と思われる（チューニング効果）。このことから，設計 の対象とする構造物，局所的な不整形構造，それに入射 する地震動の 3 者に共通して影響が卓越する波長の波動 成分の増幅を適切に評価しているかが重要である.

本検討では，不整形構造として表層地盤層厚や基盤不 整形構造の水平方向への広がりが数 $10 \sim 100 \mathrm{~m}$ 前後程度の ディメンジョンのものを対象としているので，この適用 範囲に特に注意する必要がある.

なお，本論文の内容は，昭和63年から平成 3 年まで土 木学会耐震工学委員会に設置された動的相互作用小委員 会(委員長 土岐憲三京都大学教授)の研究課題18) の一つ として著者等が担当した研究の成果に修正を加えたもの である．末筆ながら同小委員会でのご指導に深謝する次 第である。

\section{参考文献}

1) Seed, R.B. et al. : Geotechnical factors controlling damage patterns in the LOMA PRIETA EARTHQUAKE of October
17, 1989,第25回土質工学研究発表会,pp.1 39,1990.

2) 例えばKawase,H. et al. : A study on the response of a soft basin for incident $S, P$ and Rayleigh waves with special reference to the long duration observed in Mexico City, Bull.Seism.Soc.Am. ,Vol.79,pp.1361 1382,1989.

3）效纐一起 : 不整形地盤における地震動,土木学会論文報 告集,No.437,pp.1 18,1991.

4) 道路橋示方書 - 同解説 V 耐震設計編, 日本道路協会, pp.83 85,1990.

5) Lysmer J. et al. : A computer program for approximate 3-D analysis of soil-structure interaction problems,EERC Report 75-30,1984.

6) 安井譲他 : 有限要素法による不整形地盤の斜め入射解 析（その1）,大林組技術研究所報,No.39,pp.103 $\sim 106,1989$.

7) 篠崎：不整形地盤域にある構造物の振動性状に関する 研究,京都大学博士論文,1983.

8) 岡本舜三：第5章沖積地盤の地震動,耐震工学,オーム 社,pp.99 105,1971.

9) 佐藤泰夫：弾性波動論, 岩波書店,pp.59 66,1978.

10）関崇夫他：傾斜基盤を有する堆積地盤の地表面応答の 簡便な計算手法,第21回地震工学研究発表会,pp.117～ 120,1991 .

11）土岐憲三他：地震動のアレー観測に基づく不整形地盤の 震動特性とその同定,京大防災年報,pp.1〜 18,1984.

12）安藤広和他：不整形地盤の振動特性が埋設管に及ほす影 響について,第21回地震工学研究発表会,pp.49〜 52,1991.

13） 今岡克也他：造成地盤及びその上に建つ構造物の振動 性状,第8回日本地震工学シンポジウム,pp.415 419,1990.

14）田村重四郎他：基盤形状が表層地盤の地震時挙動に及 ほす影響に関する基礎的考察,第20回地震工学研究発表 会,pp.145 148,1989.

15）竹宮宏和他：不整形沖積地盤の2次元非線形解析,第 21 回地震工学研究発表会,pp.69 72,1991.

16) Tokida,K. et al. : Effects of geological irregularities on ground motion characteristics,10WCEE,pp.669 672,1992.

17) 川島一彦他：減衰定数に対する地震応答スペクトルの 補正法,土木学会論文報告集,No.344,pp.351 355,1991.

18）土木学会耐震工学委員会動的相互作用小委員会編： 基礎·地盤・構造物系の動的相互作用-相互作用効果の 耐震設計への導入-,第II編,pp.4〜 19,1992.

(1993. 7.1 受付)

\section{INTRODUCTION OF TOPOGRAPHICAL EFFECTS ON SITE RESPONSE FOR DESIGN SPECTRA}

Joji EJIRI and Yozo GOTO

Based on both the numerical simulations and the theory of elastic waves,we proposed the simple formulation which can predict site response affected by topographical irregularities in the form of design spectra. In order to verify the site response predicted using our proposed formulation, the results from two dimensional earthquake response analyses conducted concerning two types of topographical models, the basin and the inclined base layer, and previous studies were compared with them. 